\title{
Hunting Billbug, Sphenophorus venatus vestitus Chittenden (Insecta: Coleoptera: Curculionidae) ${ }^{1}$
}

Robert E. Woodruff ${ }^{2}$

\section{Introduction}

The hunting billbug, Sphenophorus venatus vestitus Chittenden, is a weevil that is also commonly known as the "zoysia billbug" in Florida, where it has been reported as a pest of various grasses, especially in nurseries. Billbug larva are often confused with white grubs, which is the name usually given to beetle larvae in the genus Phyllophaga, family Scarabaeidae.

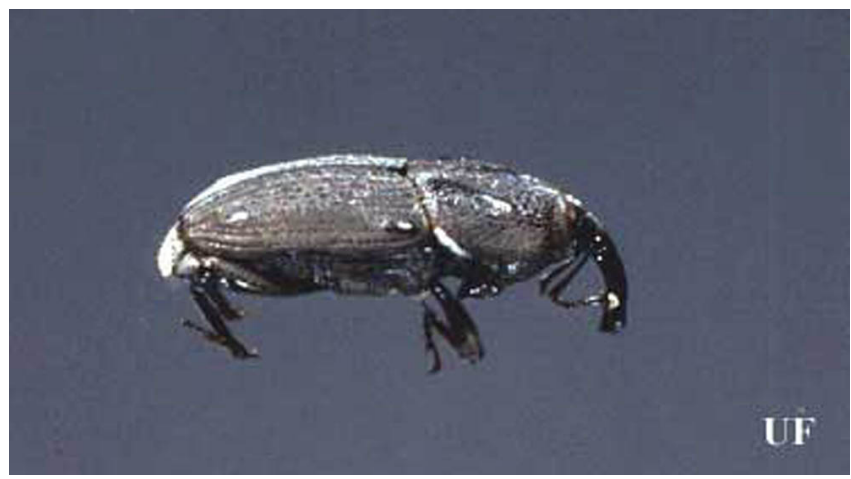

Figure 1. Adult hunting billbug, Sphenophorus venatus vestitus Chittenden. Credits: University of Florida

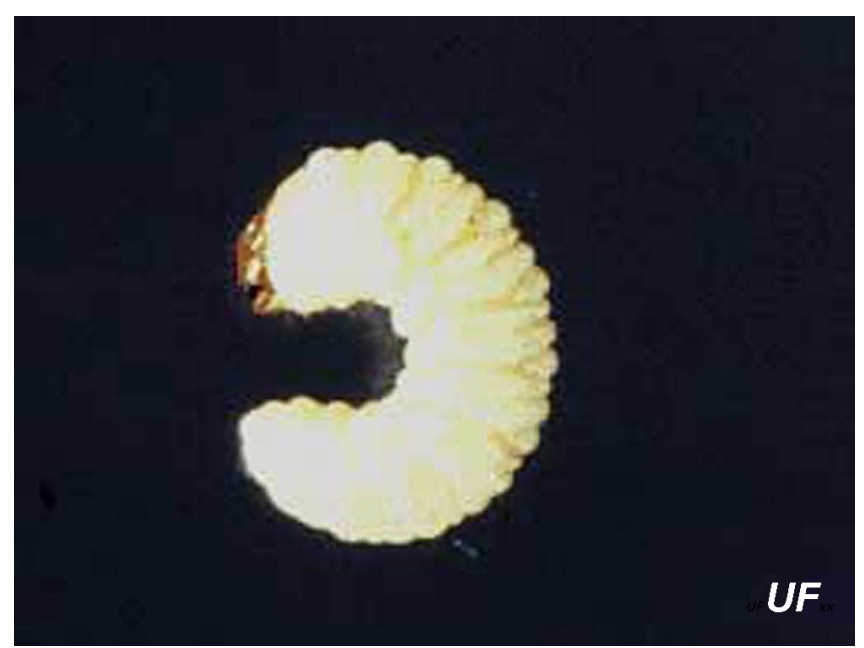

Figure 2. Larva of the hunting billbug, Sphenophorus venatus vestitus Chittenden. Credits: University of Florida

\section{Taxonomy}

The genus Sphenophorus contains 64 species in the United States, with 20 of these being recorded from Florida (Vaurie 1951). Sphenophorus venatus (Say) has been divided into five subspecies, of which only one (vestitus Chitt.) is found in the southeast. This genus was previously called Calandra and Calendra, but these names have been suppressed in favor of Sphenophorus by the International

1. This document is EENY-207 (originally published as DPI Entomology Circular 45), one of a series of Featured Creatures from the Entomology and Nematology Department, Florida Cooperative Extension Service, Institute of Food and Agricultural Sciences, University of Florida. Published: May 2001. This document is also available on Featured Creatures Website at http://creatures.ifas.ufl.edu. Please visit the EDIS Website at http://edis.ifas.ufl.edu and the Entomology and Nematology Department website at http://entnemdept.ifas.ufl.edu/.

2. Robert E. Woodruff, Florida Department of Agriculture and Consumer Services, Division of Plant Industry, Gainesville, FL.

The Institute of Food and Agricultural Sciences (IFAS) is an Equal Employment Opportunity - Affirmative Action Employer authorized to provide research, educational information and other services only to individuals and institutions that function without regard to race, creed, color, religion, age, disability, sex, sexual orientation, marital status, national origin, political opinions or affiliations. For information on obtaining other extension publications, contact your county Cooperative Extension Service office. Florida Cooperative Extension Service / Institute of Food and Agricultural Sciences / University of Florida / Larry R. Arrington, Interim Dean 
Commission on Zoological Nomenclature (1959).

Specimens of this group are often difficult to identify and should be sent to a specialist for confirmation.

\section{Distribution}

Vaurie (1951) records the hunting billbug from Alabama, Arkansas, District of Columbia, Florida, Georgia, Kansas, Louisiana, Mississippi, Missouri, North Carolina, South Carolina, Texas and Virginia, as well as the Bahamas, Cuba, Dominican Republic, and Puerto Rico.

\section{Description}

\section{Adult}

The adult is 6 to $11 \mathrm{~mm}$ in length. It is typically weevil-like in appearance with a short, fairly broad, recurved snout. The color is variable from gray to black with reddish or brown areas sometimes visible. The body surface is often coated with soil as well as a naturally pruinose, clayey coating, giving the weevil a dirty appearance. Specimens are also susceptible to greasing from body oils. These two conditions are responsible for considerable variation in appearance. The pronotum is coarsely punctate except for a "Y"-shaped area in the center and a parenthesis-like marking on each side. This pattern is characteristic of the species.

\section{Larva}

The larva is typical of most weevil larvae, being thickest at the middle. The body is white to yellowish, the head tan to brown and mandibles mostly black.

\section{Biology}

Most of the details of the life history are not known. According to Kelsheimer (1956), the eggs are laid in the leaf sheaths or top of the crown; they hatch in three to ten days, and the newly emerged larvae feed on the inner leaves as they work their way to the roots. Larvae have been found at depths of eight inches, and although as many as 72 per square foot were reported, the average find was 10 to 14 . Pupation in the soil or in the roots occurs after three to five weeks. The pupal period was noted as three to seven days. Adults have been found every month of

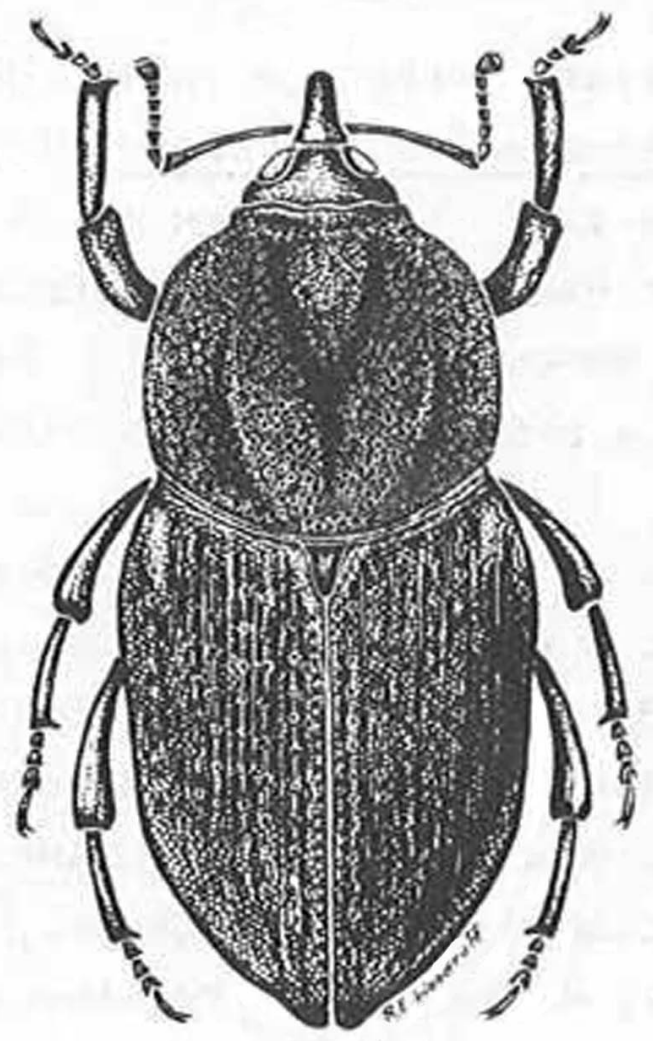

UF

Figure 3. Adult hunting billbug, Sphenophorus venatus vestitus Chittenden. Credits: University of Florida

the year, but most activity has been noted in the fall and winter.

\section{Hosts}

Nearly all the members of this genus feed on grasses and sedges. Most of the damage results when lawn grasses are planted in areas which formerly had high populations on natural grass and sedge cover. This seems to be particularly true in moist areas such as the muckland around Lake Okeechobee which is used for commercial sod production.

By far, the most commonly recorded host in Florida is zoysiagrass (Zoysia matrella (L.) Merr.). Other hosts recorded in Florida are: Bermudagrass (Cynodon dactylon (L.) Pers.), Pensacola Bahiagrass (Paspalum notatum Flugge), St. Augustinegrass (Stenotaphrum secundatum (Walt. Kunze), centipedegrass (Eremochloa ophiuroides (Munro) Hack.), corn (Zea mays L.), sugarcane (Saccharum officinarum L.) and leather-leaf fern (Polystichum adiantiforme J. Smith). Satterthwait (1931) listed 


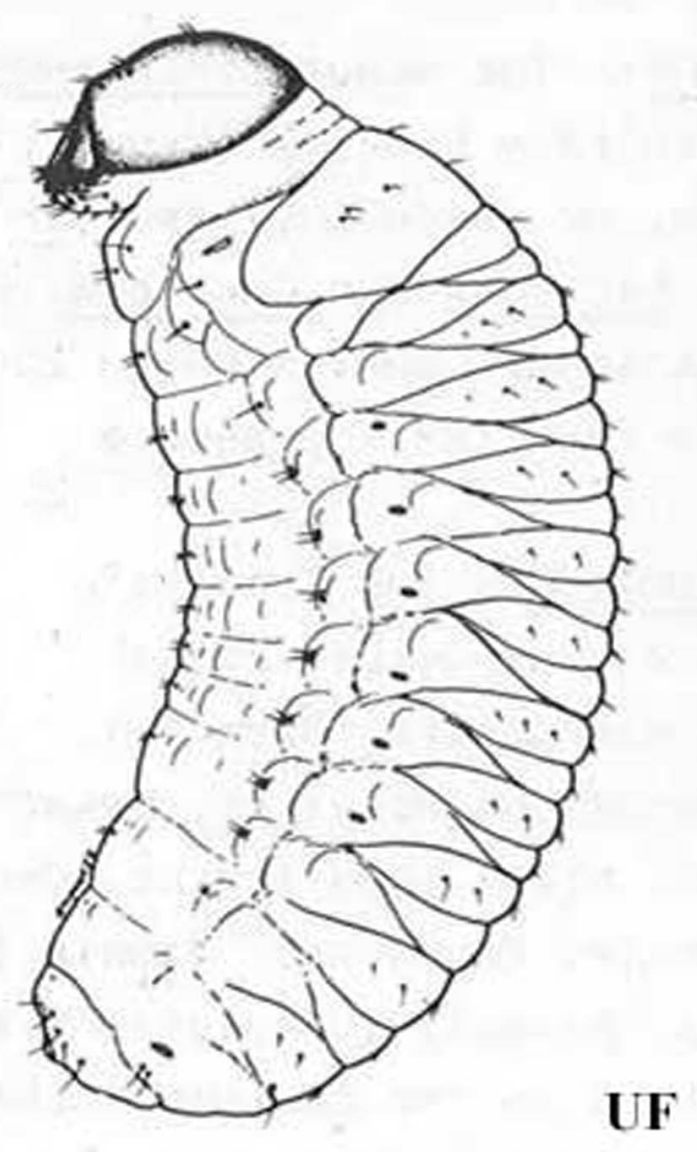

Figure 4. Larva of the hunting billbug, Sphenophorus venatus vestitus Chittenden. Credits: University of Florida

hosts for $S$. venatus, some of which might apply to $S$. vestitus: yellow nut grass (Cyperus esculentus L.), wheat (Triticum aestivum L.), timothy (Phleum pratense L.), and a bulrush (Scirpus validus Vahl.).

\section{Economic Importance}

Kerr (1964) stated that this species is not a major turf pest in Florida, but it is primarily a pest of zoysiagrass in nurseries. The damage is most serious on the roots, but young larvae apparently cause some leaf or shoot damage. Kelsheimer (1956) noted that the damage caused problems in handling the cut sod squares for shipment. The root system is often so weakened that the squares will not hold together.

\section{Damage usually first appears as yellow spots} only a few inches in diameter, but these spots will gradually become larger as feeding continues. Heavy infestations completely destroy the roots, and the grass can be rolled back like a carpet. Moles, skunks, and armadillos feed on the grubs and may damage the lawn searching for them.

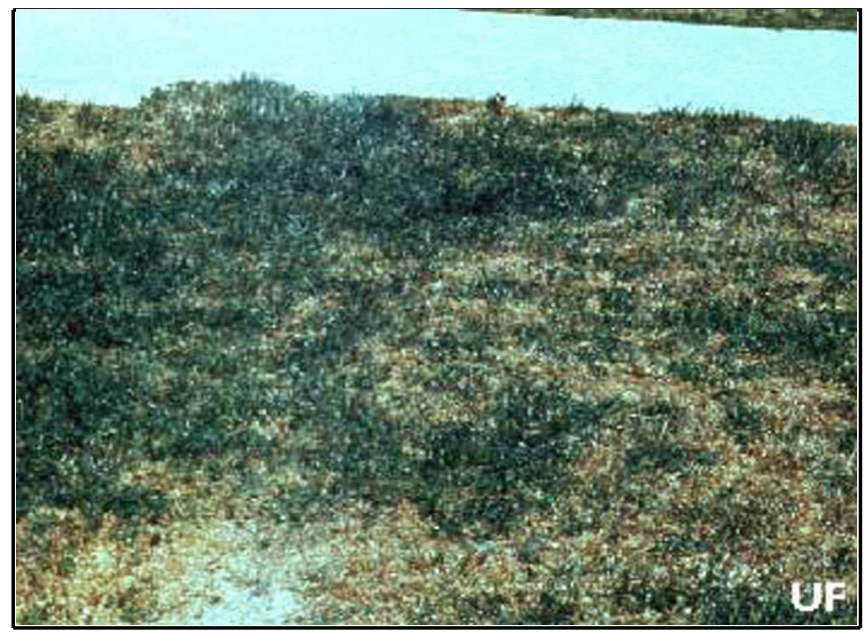

Figure 5.

To inspect for billbugs or grubs, cut three sides of a one foot square piece of sod about two inches deep with a spade under the sod and lay it back. See if the grass roots are chewed off and sift through the soil to determine if larvae are present. Replace the strip of sod. Inspect several areas in the lawn. As a rule of thumb, if an average of ten billbugs is found per square foot, apply an insecticide.

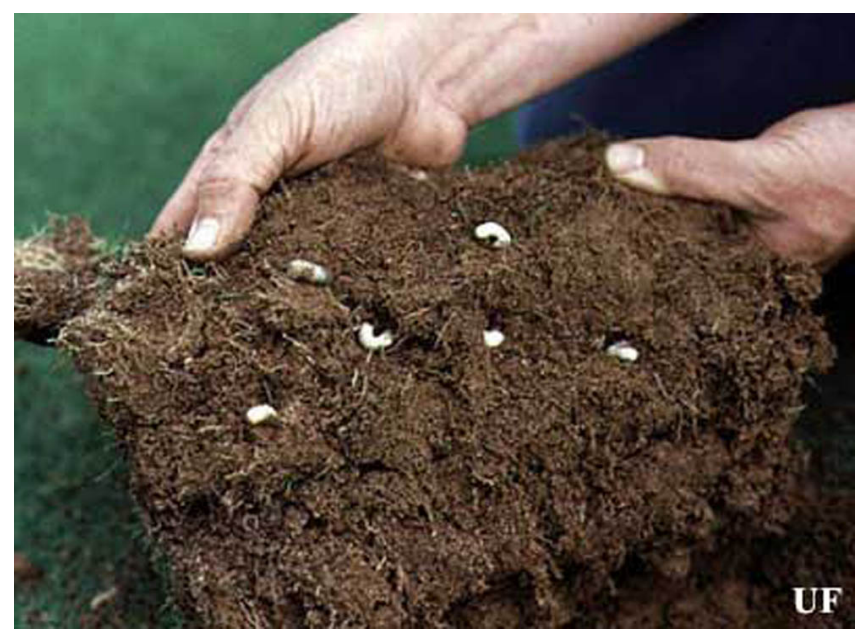

Figure 6. Inspecting for larvae of the adult hunting billbug, Sphenophorus venatus vestitus Chittenden, and white grubs of the genus Phyllophaga. Credits: University of Florida

\section{Management}

If necessary, several insecticides are successful in controlling this pest. 


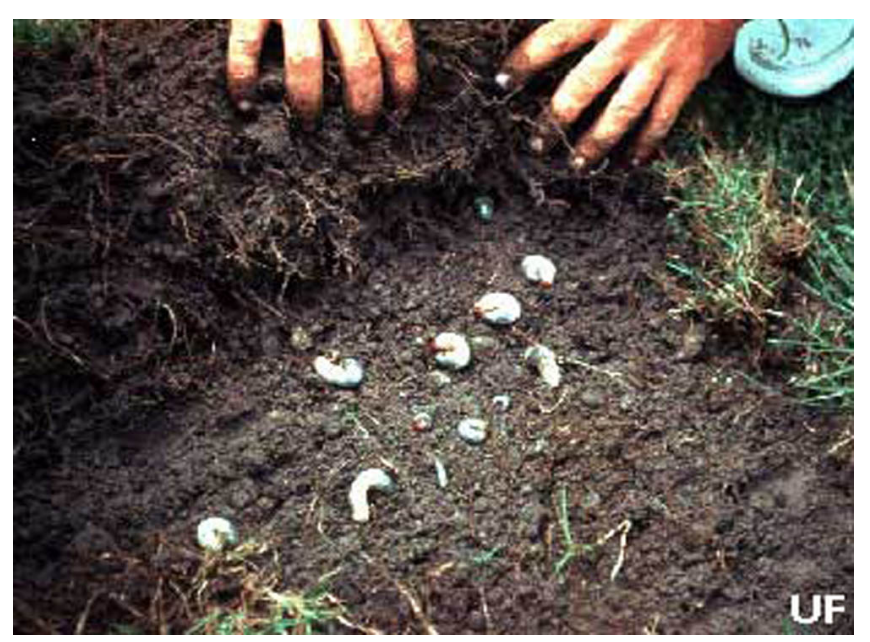

Figure 7. Counting larvae of the adult hunting billbug, Sphenophorus venatus vestitus Chittenden, and white grubs of the genus Phyllophaga. Credits: University of Florida

For more information, please see :Insect Management Guide for Turfgrass (

http://edis.ifas.ufl.edu/

TOPIC_GUIDE_IG_Turf_and_Ornamentals).

\section{Selected References}

Blatchley WS, Leng CW. 1916. Rhynchophora or Weevils of North Eastern America. Nature Publishing Co., Indianapolis, IN. 682 p.

International Commission on Zoological Nomenclature. 1959. Bull. Zool. Nomenclature 17: 112-116.

Kelsheimer EG. 1956. The hunting billbug, a serious pest of zoysia. Proceedings of the Florida State Horticultural Society 69: 415-418.

Kerr SH. 1964. Control of hunting billbugs. Florida Entomologist 47: 269-270.

Kissinger DG. 1964. Curculionidae of America North of Mexico, a Key to the Genera. Taxonomic Publications, South Lancaster, PA. 143 p.

Koehler PG, Short DE, Fasulo TR. (1998). Pests In and Around the Home. UF/IFAS. SW-126.

Satterthwait AF. 1931. Key to known pupae of the genus Calendra, with host-plant and distribution notes. Annals of the Entomological Society of America 24: 143-172.
Short DE. (1997). White grubs and billbugs in home lawns. EDIS. http://edis.ifas.ufl.edu/LH037 (3 April 2001).

Vaurie P. 1951. Revision of the genus Calendra (formerly Sphenophorus) in the United States and Mexico (Coleoptera: Curculionidae). Bulletin of the American Museum of Natural History 98: 33-186. 